\title{
Comentário:
}

\section{O HOMEM E A MÁQUINA, DIFÍCIL CONCILIAÇÃO?}

\author{
Jelson Oliveira ${ }^{1}$
}

Referência do artigo comentado: BENGOETXEA, J. B. Tecnologías para una sociedad abierta posthumana. Trans/Form/Açáo: revista de filosofia da Unesp, vol. 44, n. 1, p. 177-200, 2021.

Bengoetxea (2021) insere-se no debate a respeito do pós-humano, a partir de uma análise sobre o fenômeno da ciborgização, e o faz, começando com aquela que considero uma das questóes mais importantes: para responder à pergunta sobre quem ou o que é um ciborg, seria preciso, antes de qualquer coisa, responder àquela que é uma das mais antigas (e segundo Kant, a mais fundamental) perguntas da filosofia, ou seja, quem é o ser humano. Para tanto, o autor do texto busca elementos da filosofia da mente (destaque para a tese da mente estendida, de Andy Clark), a fim de traçar uma resposta que questione a centralidade da mente, na definição do ente humano. Fugir do isolamento cerebral da mente acaba, por isso, por ser um aspecto importante para pensar uma resposta plausível para os problemas levantados pelo avanço da tecnologia e para a chamada transição do ser humano, tal como o conhecemos até agora, até o pós-humano.

Em seu espírito ensaístico, o artigo deixa, contudo, questóes em suspenso (talvez mesmo de propósito). Destaco duas apenas: [1] qual a relação

1 Professor do Programa de Pós-Graduação da PUCPR, Curitiba, PR - Brasil. (DD https://orcid. org/0000-0002-2362-0494. E-mail: jelson.oliveira@pucpr.br.

https://doi.org/10.1590/0101-3173.2021.v44n1.13.p201

\section{(i)}


do pós-humanismo com o transumanismo; [2] quais as vantagens culturais trazidas pela ciborgologia, para a revisão de muitas características que têm sido, ao longo da nossa história, associadas ao propriamente humano e que, no fundo, deram origem a muitos desafios hoje apontados como centrais (racismo, antropocentrismo, machismo etc.). De um lado, creio, é preciso reconhecer que o transumanismo tem sido entendido como um movimento herdeiro das principais premissas do humanismo e, nesse sentido, também de seus equívocos; o que nem sempre acontece com o pós-humanismo que, em algumas de suas vertentes, tem se mostrado radicalmente crítico de muitos dos valores centrais do humanismo (esse é o caso, por exemplo, do pós-humanismo crítico). De outro lado, os avanços críticos devem ser reconhecidos, quando contrapomos o humanismo com suas próprias falhas históricas, principalmente no que diz respeito à efetivação de modelos de mundo autoritários, injustos e desiguais.

Além disso, ressalto um ponto que o artigo não desenvolve, mas parece se contrapor: segundo o texto, os críticos do pós-humanismo estão sempre contra o avanço tecnológico e seriam "fundamentalistas". Essa é uma afirmação recorrente entre aqueles que não consideram os aspectos éticos e políticos (quiçá também os econômicos), na avaliação desses processos: as questóes levantadas pelos bioeticistas (que eu prefiro chamar de biodefensores, em substituição ao simplista e já ideologicamente carregado bioconservadores) não devem ser rasamente associadas ao fundamentalismo ou à tecnofobia. Esse é um equívoco que apenas serve para que a tecnologia continue embarcada em seu aspecto utópico, incentivada por uma história de êxitos que pretende facilmente ganhar adeptos e defensores que fechem os olhos para os perigos e riscos trazidos pelo avanço das biotecnologias. Léon Kass, nesse caso, não tem a palavra final. E as perguntas éticas não podem sempre ser ligadas a uma "retórica antitencológica" que apenas pretende atrasar o avanço (ademais, inquestionável) da tecnologia.

A tecnofobia não é produto da ética, mas do medo exacerbado que nasce - também - das próprias experiências inadequadas, erros, acidentes e prejuízos trazidos por vários procedimentos tecnológicos, alguns dos quais eram promessas de melhoria. Nesse caso, o pós-humanismo crítico talvez possa fornecer elementos interessantes para a reflexão daquilo que é o ponto inicial do artigo e que diz respeito ao questionamento de ideais tradicionais, como identidade, subjetividade, liberdade e responsabilidade, na medida em que rejeitam as velhas hierarquias entre os seres em benefício de uma 
visão vinculante e, de alguma forma, também não-dualista. A perspectiva de descontrução desses quase-dogmas talvez seja o produto mais benéfico da reflexão imposta pelo advento do ciborg e seu anúncio (ainda prematuro, claro) de um novo horizonte de abertura para a retomada cultural da ideia de ser humano e sua missão neste planeta - ele mesmo também uma agregação de fenômenos e circunstâncias, impactos e acidentes produzidos pela relação estabelecida com o seu entorno.

Assim, a relação com as máquinas também deve ser reconhecida como um capítulo importante de interação autoconstrutiva e de dinâmica híbrida, na qual a biologia se articula com a tecnologia. Entretanto, isso não significa que tal conexão é, de todo, alheia a problemas éticos ou que isso será sempre algo benéfico para o ser humano. $\mathrm{O}$ intercâmbio simbiótico entre o ser humano e as máquinas, sendo algo aparentemente inevitável, deve sempre nos levar às fronteiras da ética, lá onde é preciso sempre perguntar como e de que forma o ser humano pode conviver - entre si, com as outras formas de vida e, agora também, com os artefatos que ele mesmo inventou. Nesse sentido, o artigo em questão oferece não apenas uma visão do problema, como aponta para um dilema central daquela que deve ser uma ética para a civilização tecnológica. A conciliação entre ser humano e máquina é a chance, portanto, para a revisão de nossas construçóes históricas e, da minha perspectiva, essa é a principal vantagem dessa reflexão e de sua problematização filosófica - tal como o texto em questão o faz.

\section{REFERÊNCIA}

BENGOETXEA, J. B. Tecnologías para una sociedad abierta posthumana. Trans/Form/ Açáo: revista de filosofia da Unesp, vol. 44, n. 1, p. 177-200, 2021.

Recebido: 09/10/2020

Aceito: 13/10/2020 
OLIVEIRA, J. 